\title{
Implementation of Library 2.0 Application: Lesson Learnt from Indonesian Library and Librarian
}

\section{Muhammad Usman Noor}

Information Management and Documents, Vocational Program, Universitas Indonesia, Depok, Indonesia

\section{Abstract}

Despite Web 2.0 application achieving impressive growth over the last decade, the application of Web 2.0 in library, which is known as Library 2.0 concept, has received less implication than Web 2.0, particularly in Indonesia Library. This article makes an attempt to show and analyze the implementation of Library 2.0 in Indonesia compared with Global implementation of Library 2.0, whilst scrutinizing the existing literature that covers the implementation of library 2.0 in Indonesia and globally.

Corresponding Author: Muhammad Usman Noor musmannbox@gmail.com

Received: 8 June 2018 Accepted: 17 July 2018 Published: 8 August 2018

Publishing services provided by Knowledge E

(c) Muhammad Usman Noor. This article is distributed under the terms of the Commons Attribution License, which permits unrestricted use and redistribution provided that the original author and source are credited.

Selection and Peer-review under the responsibility of the $2 n d$ ICVHE Conference Committee. More specifically, this article examines the implementation of Library 2.0 from 2006 to 2016 and that why Indonesian library did not yet enjoy the full benefit of Library 2.0 as other regions or nations. It finds that although there were great opportunities from internet users in Indonesia, library Indonesia still struggled to take all the benefits from the implementation of library 2.0 in Indonesia.

Keywords: Web 2.0, library 2.0, Indonesia, social media, library

\section{Background}

Despite Web 2.0 application achieving impressive growth over last decade, application of Web 2.0 in library, which is known as Library 2.0 concept has received less implication than Web 2.0 effects. Emerge of Web 2.0 not only in Indonesia, but also as global. Practically, almost all website and web platform are compatible to Web 2.0 such as content collaboration creation and user participation. Social media, one of Web 2.0 application also become most popular website. Data shows, 18 of 20 the most popular websites worldwide in 2016 according to the top 100 lists published by Alexa Internet, are Web 2.0 web based. It shows Web 2.0 concept are regain highest popularity in web.

Web 2.0 derived to many sub concept, such as Library 2.0. Not only in Library sphere, others are too like Social work, Enterprise, PR, Classroom, Publishing, Medicine, Telco, Travel, Government, even Porn 2.0. All of them term coined with 2.0 appendage. Instead Web 2.0 popularity in common web, Library 2.0 concept still struggle to make 
impact in Library context. Particularly in Indonesia, which is Library 2.0 are still concept that not every library adopted well.

Internet users in Indonesia reached 132.7 billion in 2016, it is about a half (51\%) of Indonesia population. Indonesian internet user behavior to access social media are high, the data said almost all of them use the internet to access social media $97.4 \%$. Meanwhile, other Web 2.0 application which is frequently accessed by Indonesia internet user is Wikipedia, 40.8\% users access to Wikipedia. [2]. From that circumstances, in daily life, Indonesian internet user Web 2.0 application for daily basis. However, the library with their concept known as Library 2.0 still struggled to gain maximum advantage of Library 2.0 despite of Web 2.0 usage are quite high.

Library 2.0 was first coined by Michael Casey on his blog LibraryCrunch in 2005. Library 2.0 is specifically made so that the library can improve services through continuous evaluation and updating the library services. Library 2.0 empowers the users by giving users the opportunity to participate in enrich their services [3]. Many Librarian information science scholar discuss and issues the term to clear what is Library 2.0 are. Key principles of library 2.0 as identified by Holmberg, interactivity, users, participation, libraries and library services, web and web 2.0, social aspects, and technology and tools [4].

This article aims at specifically to closing research gap by clarifying the struggles of implementation of Library 2.0 in Indonesia Library. It focuses on the links between Web 2.0 rises in generally, despite Library 2.0 in Indonesia remains struggling to optimized by Indonesia Library as overall. More specifically, the authors explore the implication of Library 2.0 concept in Indonesia.

This article is organized as follows. Section 2 will summarize major scholarly works on implementation of Web 2.0 and Library 2.0 concept, both in world in generally and in Indonesia particularly, which will be used to developed a framework for analyzing relationship between these two concepts. Section 3 examines relation between the implementation and implication of Library 2.0 in Indonesia and globally over last decade with. Section 4 will clarify the prevalence on Web 2.0 on others sector, and how Indonesia Library optimize Library 2.0 concept. Finally, section 5 concludes and outlines possible avenues for future research.

\section{Web 2.0 and Library 2.0 Core Concept}

\subsection{Web 2.0}

Web 2.0 doesn't have a hard boundary, but rather, a gravitational core. More over Reilly describe Web 2.0 definition is the network as platform, spanning all connected devices; Web 2.0 applications are those that make the most of the intrinsic advantages 
of that platform: delivering software as a continually updated service that gets better the more people use it, consuming and remixing data from multiple sources, including individual users, while providing their own data and services in a form that allows remixing by others, creating network effects through an 'architecture of participation', and going beyond the page metaphor of Web 1.0 to deliver rich user experiences $[13,14]$. Another definition about Web 2.0 has been cited, said Web 2.0 is the second generation of web development, which allows people to collaborate, interact, and share information online. It is a dynamic, user-centered environment that encourages two-way communication [6].

\subsection{Library $\mathbf{2 . 0}$}

The template is used to format your paper and style the text. All margins, column widths, line spaces, and text fonts are prescribed; please do not alter them. You may note peculiarities. For example, the head margin in this template measures proportionately more than is customary. This measurement and others are deliberate, using specifications that anticipate your paper as one part of the entire proceedings, and not as an independent document. Please do not revise any of the current designations. Seven core components of Library 2.0 are interactivity, users, participation, libraries and library services, web and web 2.0, social aspects, and technology and tools. From these building block we can empirically define Library 2.0. Library 2.0 is a change in interaction between users and libraries in a new culture of participation catalyzed by social web technologies, as in the following figure [4].

In other hand, Chua, Goh, \& Lee (2008) describe Library 2.0 application as three main categorize, (1) information push/pull (2) information retrieval and (3) information exchange. Information push or pull stands for RSS, Blogs, and Wikis. Social tagging stands for Information retrieval, when instant messaging and social networking are stand for Information exchange. Thus, seven type of applications are represent application of Library 2.0 concept. Holmberg et al elaborate 2.0 concept to seven core components, when Chua, Goh, and Lee specifically divide Library 2.0 concept to application on the web. Most distinguished between Library 1.0 to Library 2.0 is user participation and relationship between librarian and users. Users took many part of the library activities. Services that brought to the users are based on users participation and realtime feedback.

\section{Library 2.0 Implementation-Globally and in Indonesia}

International study was conducted by Harinarayan and Raju (2010 on Mahmood, 2011). They selected 100 universities form the lists of world university rankings. Fifty-seven 


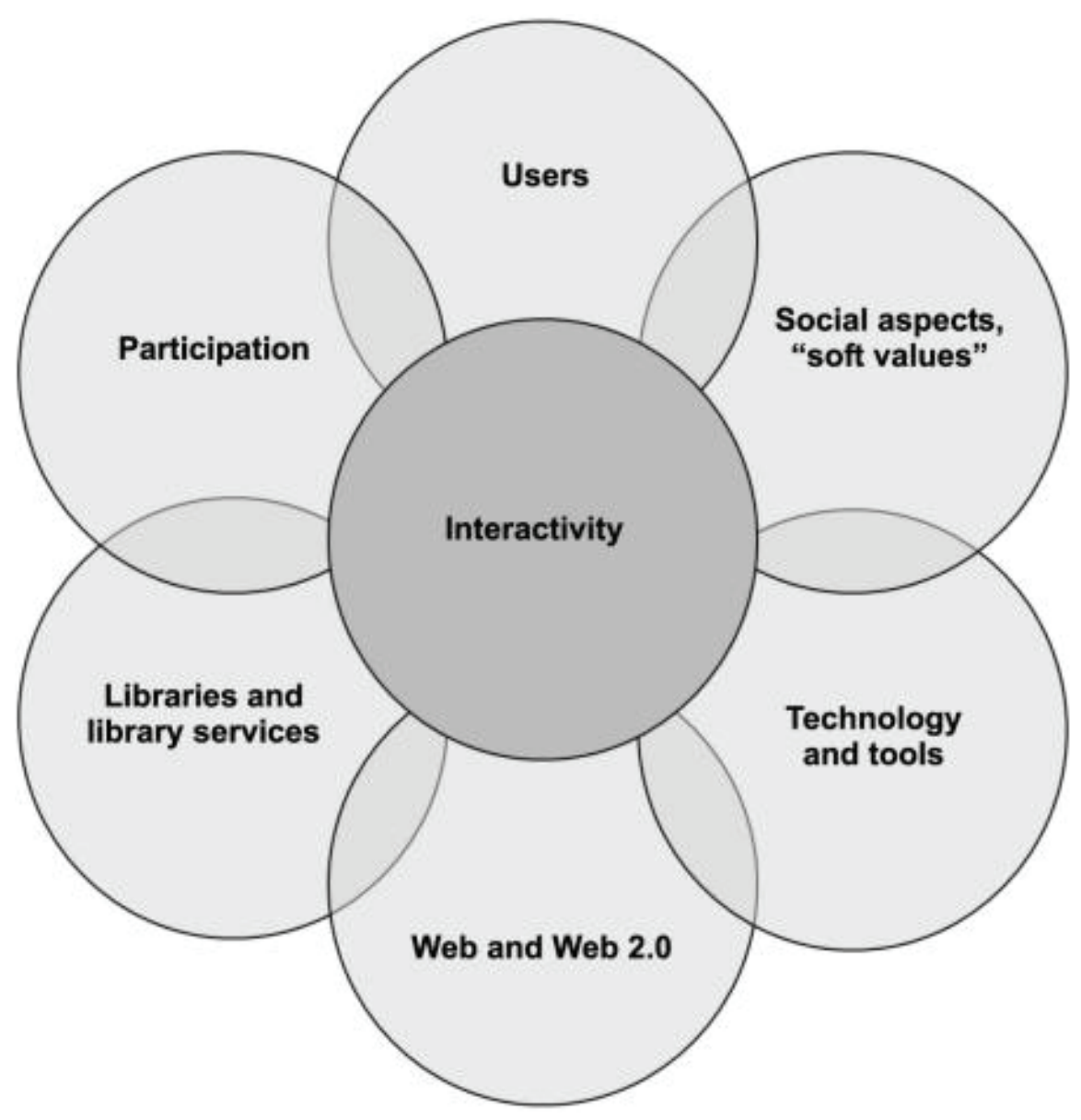

Figure 1: Building blocks of Library 2.0 Core concept [4].

universities we offer at least one Web 2.0 service. RSS and IM were used by thirtyseven libraries and blogs were offered by fifteen libraries. Wiki, podcast, and vodcast were among the least used technologies. For better explained about prior paper about Library 2.0 application in worldwide library, these table are compiled from Mahmood (2011) dissertation about Library 2.0.

From the aforementioned table, we can compare implementation of Library 2.0 in regional USA is high, from many types of libraries in America, almost of them have utilized Library 2.0 application on their Library. In general, implementation of Library 2.0 in more developed countries libraries has grown since library 2.0 concept newly coined. Utilization of Library 2.0 concept is not limited to just one type of library 2.0 application but has spread across various services, thus in overall they had gather potent of Library 2.0 concept and implementation.

In contrast, Different conditions are experienced in many Asian fellows. In general, many library in Asia have utilized Library 2.0, yet did not reach maximum potential. This is evident from the research that discusses the implementation of Library 2.0 in the Asia-Pacific region. One of these, Chua et al paper showed that the use of Web 2.o applications in the Library of the Library in Europe, America, and Asia indicate that 
TABLE 1: Implementation of Web 2.0 application in Library [9]. Compiled by Noor, 2017.

\begin{tabular}{|c|c|c|c|c|c|c|c|c|c|}
\hline \multicolumn{10}{|c|}{ Web 2.0-based Application (in \% ratio) } \\
\hline Author Name & Year & $\begin{array}{c}\text { Total } \\
\text { Sample }\end{array}$ & $\begin{array}{l}\text { Kind of } \\
\text { Library }\end{array}$ & Location & RSS & Blogs & IM & $\begin{array}{c}\text { Social } \\
\text { Network }\end{array}$ & Podcast \\
\hline $\begin{array}{l}\text { Tripathi and } \\
\text { Kumar }\end{array}$ & 2010 & 277 & $\begin{array}{l}\text { Academic } \\
\text { Library }\end{array}$ & $\begin{array}{c}\text { Australia, } \\
\text { Canada, UK, } \\
\text { USA }\end{array}$ & 31.4 & 33.2 & 43.7 & & \\
\hline $\begin{array}{l}\text { Kim and } \\
\text { Abbas }\end{array}$ & 2010 & 230 & $\begin{array}{c}\text { Academic } \\
\text { Library }\end{array}$ & Worldwide & 73 & 65 & & 15 & \\
\hline $\begin{array}{l}\text { Harinarayana } \\
\text { and Raju }\end{array}$ & 2010 & 100 & $\begin{array}{l}\text { Academic } \\
\text { Library }\end{array}$ & Worldwide & 57 & 15 & 37 & & \\
\hline $\begin{array}{l}\text { Shoniwa and } \\
\text { Hall }\end{array}$ & 2007 & 152 & $\begin{array}{c}\text { Academic } \\
\text { Library }\end{array}$ & UK & 18 & 11 & & & 5 \\
\hline Linh & 2008 & 47 & $\begin{array}{l}\text { Academic } \\
\text { Library }\end{array}$ & $\begin{array}{l}\text { Australia } \\
\text { and New } \\
\text { Zealand }\end{array}$ & 63.8 & 36.2 & 10.6 & & 21.3 \\
\hline $\begin{array}{l}\text { Bejune and } \\
\text { Ronan }\end{array}$ & 2008 & 64 & Mixed & USA & 84 & 82 & 94 & 70 & 62 \\
\hline Rogers & 2009 & 148 & Mixed & USA & & 70.7 & 50.7 & 66.7 & \\
\hline $\begin{array}{l}\text { Jenda and } \\
\text { Kesselman }\end{array}$ & 2008 & 118 & $\begin{array}{l}\text { Special } \\
\text { Library }\end{array}$ & USA & & 32 & 54 & & \\
\hline $\begin{array}{l}\text { Smeaton and } \\
\text { Davis }\end{array}$ & 2014 & 26 & $\begin{array}{l}\text { Public } \\
\text { Library }\end{array}$ & Australia & & 65.3 & & 84.6 & 19.2 \\
\hline
\end{tabular}

the use of web 2.0 in Asia is far lower, One reason is because almost all web services generally use English, while English most not the primary language of countries in Asia [18]. Internet sphere uses English as its international language, since then many new technologies that are difficult to internalize in some societies, especially those who do not really speak English fluently. Language constraints and barrier in web 2.0 applications are a problem in many Asian countries that do not use English as their primary language. As for some countries whose English proficiency has been good as Singapore or India shows the implementation of Library 2.0 more seamlessly accepted by the librarian as well as its users. For example, In India, emergence of web 2.0 is being positively perceived by libraries as an opportunity to advance their services and offerings. It is concluded from the study that the library and information science professionals of the engineering college in Chennai city are well aware with the modern concepts like web 2.0. They use these concepts. But they implement it very less as far as rendering or library services are concerned [17]. From the past paper which is discuss about the implementation of Library 2.0 shows, Europe and American native are familiar to utilize Library 2.0 concept when Asia-Pacific-based libraries are still struggled in general. 
Implementation of Library 2.0 in Indonesia can be observed from the past research which discuss Library 2.0 in Indonesia. The implementation of Library 2.0 in Indonesia has started since the internet became a common thing in the 2000 s.

Information that contained in web 2.0 as library services in Indonesia usually inform and to announce the patron about activities to be undertaken by libraries and other news library such as, library agendas, library activity photos, library profile videos. Likely, library in Indonesia use Web 2.0 application in example instant messaging to provide interaction between users and librarian. [1]. Content are point to concern, because the library actually has a lot of content that can be displayed, but in practice, many content in library social media is not attractive, yet monotonous. Not only focus on domestic work or activities undertaken by the library, the library could remake information they had in their collection to more attractive visualization. Appeal more users to participate in social media by attractive content in library social media is the key.

TABLE 2: Type of Web 2.0 used in the Library of Higher Education in Indonesia [1].

\begin{tabular}{l|l|l|} 
Web 2.0 & $F$ & $\%$ \\
\hline Facebook & 28 & 70 \\
\hline Twitter & 19 & 47.5 \\
\hline RSS & 14 & 35 \\
\hline Flickr & 4 & 10 \\
\hline YouTube & 8 & 20 \\
\hline Instant Messaging & 8 & 20 \\
\hline
\end{tabular}

In some case, academic library which already use Library 2.0 feature, Universitas Indonesia library owned library twitter account which is followed by more than 16777 accounts as of August 2014. This amount puts UI Library account into account academic libraries that have the largest number of followers in Indonesia. UI Library account with the account name @UI_library become one of the most active accounts with the average tweets per day or 3.3 post 99 tweets per month. Therefore, participation in the twitter users UI Library is already quite high [12].

The use of microblogging, particularly twitter, in the academic library in Indonesia can be said is still not very popular, the data until 2014, from all state universities in Indonesia only 16 of them that already have twitter. As for the utilization, there are still many who just make an account only without developing or running social media [10]. In general, application of Library 2.0 in Indonesia from the results of previous research is still lacking, because some things. Among other things, not updated regularly or less actively in running it, the implementation of Library 2.0 only as a complement 


\begin{tabular}{|c|c|c|c|c|c|c|c|c|}
\hline No & Nama Universitas & Fakultas & Nama Akun & Id akun & Tweets & Following & Follower & Dibuat \\
\hline 1 & Universitas Indonesia & & UI Library & @UI library & \begin{tabular}{|r|}
1423 \\
\end{tabular} & 61 & 16777 & Apr-11 \\
\hline 2 & Universitas Indonesia & Kedokteran & Perpustakaan FKUI & $@$ @KUUI Library & 2544 & 58 & 706 & Mar-12 \\
\hline 3 & Universitas Gajah Mada & & Library of UGM & @UGMLibrary & 523 & 466 & 690 & Jun-13 \\
\hline 4 & Universitas Bengkulu & & UPT Perpus UNIB & $@$ Perpus Unib2013 & 2 & 21 & 33 & Jun-11 \\
\hline 5 & Universitas Pendidikan Indonesia & & Perpustakaan UPI & @perpustakaanupi & 358 & 31 & 1599 & Jun-11 \\
\hline 6 & Universitas Pendidikan Indonesia & Sastra & Perpustakaan Sasing & @EngLibrary & 668 & 239 & 763 & Jun-12 \\
\hline 7 & Universitas Negeri Semarang & & UPT Perpustakaan UNS & @perpustakaanuns & 2 & 6 & 4 & Nov-13 \\
\hline 8 & Politeknik Negeri Semarang & Elekto & PJE Polines & $@$ @jepolines & 1 & 24 & 8 & Feb-14 \\
\hline 9 & Universitas Negeri Yogyakarta & Sastra & PERPUSTAKAAN FBS & @PERPUSTAKAANFH & 8 & 64 & 81 & Feb-12 \\
\hline 10 & Universitas Negeri Yogyakarta & IImu Pendidika & Perpustakaan FIP UNY & @PerpusFIPUNY & 530 & 7 & 177 & Apr-12 \\
\hline 11 & Universitas Negeri Yogyakarta & IImu Sosial & perpustakaan fis uny & @perpusfisuny & 334 & 340 & 285 & May-12 \\
\hline 12 & Institut Teknologi Surabaya & & UPT Perpustakaan ITS & $@$ & 5 & 105 & 257 & Jul-12 \\
\hline 13 & Universitas Airlangga & & Perpustakaan UNAIR & @unairlibrary & 7321 & 129 & 4038 & Dec-11 \\
\hline 14 & Universitas Negeri Jember & & DIGILIB UNEJ & $@$ @ibrary unej & 2 & 19 & 21 & May-13 \\
\hline 15 & Universitas Hasanuddin & & Perpustakaan UnHas & $@$ @nHas Library & 40 & 157 & 105 & Jan-13 \\
\hline 16 & Universitas Negeri Jakarta & & UPT Perpustakaan UNJ & $@$ PerpustakaanUNJ & 79 & 15 & 126 & Oct-13 \\
\hline
\end{tabular}

Figure 2: Indonesia Academic Library twitter accounts statistic [10].

$[1,8]$. That is often missed by the policy holders in the library. Implementation of Library 2.0 not even done in established process, but needs to be developed and maintained as well. Maintenance process was the important parts and requires a skilled librarian. Social media as one of the Library 2.0 applications requires continuous of useful contents, so users are interested to follow and participate in the network.

To ensure the success of a Twitter account, libraries must tweet regularly (two to three times per day) and ensure the account is used for engagement (Cahill 2011, Tagtmeier 2010, Fields 2010, Loudon \& Hall 2010, King \& Willen Brown 2009, Steiner 2009, Stuart 2010, Fitcher 2007 on [15]). One of the causes of Web 2.0 implementation still struggle in Indonesia, is not many libraries that use social media to the proper way. As for many libraries that already have social media but do not take care of it, rarely update, never post, and no particular librarian to nurture and maintain social media in the Library [8]. Despite, library who treat their social media with post routine enjoy a lot of user participation, one of which in Indonesia is social media Library of Universitas Indonesia and Indonesia National Library $[11,12,19]$. So from the aforementioned figures, the key to success in the implementation of Library 2.0 is the continuity of maintenance by the library.

Moreover, lack of understanding of Library 2.0 concept by Indonesia librarian and users are made implementation Library 2.0 di Indonesia struggle still $[5,7]$. Library 2.0 are complex nor not as simple as social media does. Social media are facilitated by Web 2.o technology. Social media or social networks such as Linkedln, Facebook, Twitter, are delivered by Web 2.0 Technologies. Thus, social media is just only one component of Web 2.0 technology.

The implementation of Library 2.0 requires support from stakeholders. Availability of supportive policies, the appropriate placement of human resources in this case, librarian, technological investments, are some of the things required for the implementation of Library 2.0 to run optimally and bring services to library users. In previous study, 
human resources with expertise and skills in the field of librarianship and information and communication technology, and financial support and leadership support are all in need [7]. Library 2.0 is often considered something that only requires internet network, whereas investment is not only in the provision of networks but also the human resources that run it. In this case, librarian skill for run library 2.0 concept are rarely in Indonesia.

\section{Discuss and Conclusion}

After the text edit has been completed, the paper is ready for the template. Duplicate the template file by using the Save As command, and use the naming convention prescribed by your conference for the name of your paper. In this newly created file, highlight all of the contents and import your prepared text file. You are now ready to style your paper; use the scroll down window on the left of the MS Word Formatting toolbar. To extract full potential of Library 2.0 application but still make sense and in accordance with user culture in Indonesia, we need a strategy for its development. Success can be done with support of all library stakeholders and all components. In addition, the adjustment of the implementation of Library 2.0 with Web 2.0 applications what has been widely used in Indonesia.

In general, Library 2.0 is application of savvy technology, in contrast stakeholders who category of late majority or even laggards in technology adoption model. which is hard to accept new technology adoption, like Library 2.o. Generally, late majority is difficult to accept new technologies or do not consider it important technology. So if only rely from top to bottom can lead to the implementation of technology becomes stagnant. Then the perpetrators of the library world who are young or known as early adopters can introduce the benefits of the application of Library 2.0 so that the policy comes from below and into policy action. As explained by Sudarsono, To develop Library 2.0 in Indonesia, National systems do not always have to be built on top-down but will be more rooted if built from the bottom up. With the working mechanism and spirit of Library 2.0 we will be able to accelerate the growth of Indonesian libraries on the right path (2009).

In addition, Role of school library in Library 2.0 implementation became crucial, particularly to introduce library and library services through technology, using the Library 2.0 application. Schools students, who are kids and teenagers who are everyday already used Web 2.0 applications in their daily life will be more suitable and easily approached by the library by using Library 2.0. It is expected that they are aware of the library because school library has been well applying library 2.0 in providing services to its users, who incidentally are still teenagers or children. So awareness of libraries can be nurtured from an early age. 
From results of past research can be seen that Web 2.0 applications that are commonly used in Indonesia is social media. Then the strategy that can be used is the library maximize the potential of social media users who are very much in Indonesia. Providing useful and targeted content, updating information, and continuing to promote the library's social media accounts are just a few things libraries can do.

But the provision of content in social media is not a trivial and light matter. Many libraries that just stop providing Library 2.0 services are limited to just there, but never updated. Blogs, social media, wikis, video sharing, instant messaging are some of the Web 2.0 apps that need specialized staff to handle them. If there is not librarian to point to handles Library 2.0 application, it can be assured that the service is not running and there is no user used that services.

To run information services called Library 2.0 with Web 2.0 applications need special qualifications from librarians to deliver information through Library 2.0-based services. Librarians must know and understand the features of the Library 2.0 application, know the information needs of potential users, and be able to repackaging information into various forms that can attract the attention of users to participate. Implementation process of library 2.0 will not run smoothly if the librarian's qualification is not sufficient, hence the science of implementing library 2.0 as a form of competence can also be proposed in the curriculum of library science schools in Indonesia.

Until now, seeing from its development, both from previous research results and from observation, Library 2.0 in general has not reached a satisfactory point in its implementation in Indonesia. Whereas on the other hand, have started their terms Library 3.0 introduced. Instead of tempting to think of Library 3.0 that began to emerge, we better focus to maximize Library 2.0 implementation which is actually still running and in other countries have been put to good use. Technology is definitely coming and going, but new technology will be useful if used maximally and accordingly.

\section{References}

[1] Anna, N. E. V. (2015). Penggunaan Web 2.0 sebagai Media Promosi Perpustakaan Perguruan Tinggi di Indonesia. Record and Library Journal, 1(1), 77-82. https://doi. org/e-ISSN 2442-5168

[2] APJII. (2016). Penetrasi \& perilaku pengguna internet indonesia.

[3] Casey, M., \& Savastinuk, L. (2007). Library 2.0: A Guide to Participatory Library Service. Public Library Journal. Medford, New Jersey iii. https://doi.org/10.1002/asi. 20773

[4] Holmberg, K., Huvila, I., Kronqvist-Berg, M., \& Widén-Wulff, G. (2009). What is Library 2.0? Journal of Documentation, 65(4), 668. https://doi.org/10.1108/ 
00220410910970294

[5] Kangko, D. D. (2011). Universitas indonesia tanggapan pustakawan dan pemustaka terhadap penerapan.

[6] Livingston, B. (2010). Using Web 2.o Technologies. Virginia: ASTD Press.

[7] Maesaroh, I. (2014). IMPLEMENTASI LIBRARY 3.0 DI PERPUSTAKAAN PTAI Oleh Imas Maesaroh, PhD 1. Jurnal Iqra, 8(2), 112-121.

[8] Mafar, F., \& Sudiar, N. (2012). PERTUMBUHAN AKUN TWITTER PERPUSTAKAAN, 179183.

[9] Mahmood, K. (2011). Impact of Web 2. o technologies on academic libraries $\rrbracket: A$ survey of ARL libraries Impact of Web 2. o technologies on academic libraries: a survey of ARL libraries, (October), 2-4. https://doi.org/10.1108/EL-04-2011-0068

[10] Noor, M. U. (2014). Penggunaan twitter di Perpustakaan Akademik di Indonesia: Potensial namun tak dimanfaatkan. In Seminar Nasional Informasi sebagai Aset Bangsa (pp. 101-115). Depok: Departemen Ilmu Perpustakaan.

[11] Noor, M. U. (2015). PENGARUH LAYANAN INFORMASI MELALUI TWITTER DI PERPUSTAKAAN UNIVERSITAS INDONESIA TERHADAP PARTISIPASI PENGGUNA. Universitas Indonesia.

[12] Noor, M. U. (2016). Impact of information services via twitter at Universitas Indonesia Library for user participation. In LIS 2016: Proceedings of the International Conference on Library and Information Science (pp. 140-157). Kyoto: International Business Academics Consortium. https://doi.org/10.1002/ejoc.201200111

[13] O'Reilly, T. (2005). What Is Web 2.0: Design Patterns and Business Models for the Next Generation of Software. O'Reilly, 1-16. Retrieved from http: //www.oreillynet.com/pub/a/oreilly/tim/news/2005/o9/30/what-is-web-20. html\%5Cnhttp://oreilly.com/lpt/a/6228

[14] O'Reilly, T. (2006). Web 2.o Compact Definition. Radar, Retrieved, o. https://doi.org/ $10.2307 / 2640276$

[15] Smeaton, K., \& Davis, K. (2014). Using social media to create a participatory library service: an Australian study. Library and Information Research, 38(117), 54-76. Retrieved from http://www.lirgjournal.org.uk/lir/ojs/index.php/lir/article/ view/593

[16] Sudarsono, B. (2009). Menerapkan Konsep Perpustakaan 2.0. Workshop Library 2.o®: Challenge and Opportunities to Library Management. Semarang.

[17] Thanuskodi, S. (2011). WEB 2. o Awareness among Library and Information Science Professionals of the Engineering Colleges in Chennai City: A Survey, 1(2), 69-75. 
[18] Yeow, A., Chua, K., Goh, D. H., \& Lee, C. S. (2008). The Prevalence and Use of Web 2. 0 in Libraries. In G. Buchanan, M. Masoodian, \& S. J. Cunningham (Eds.), Digital Libraries: Universal adn Ubiquitous Access to Information (pp. 22-30). Bali: Springer.

[19] Yunianto, H., Saleh, A. R., \& Mulyani, E. S. (2007). HUBUNGAN DIMENSI KEPERCAYAAN DENGAN PARTISIPASI PEMUSTAKA MELALUI FACEBOOK FAN PAGE (STUDI LIBRARY 2.0 DI PERPUSTAKAAN NASIONAL RI). Jurnal Pustakawan Indonesia, 14(1), 23-32. 